\title{
The Role of Asset Disclosure and Registration Law in Combating Corruption in Ethiopia: A Comparative Analysis with the Hong Kong and Rwanda Legal Systems
}

\author{
Diriba Adugna Tulu \\ Public Prosecutor at Attorney General Office Of Oromia Regional State, Ethiopia
}

\begin{abstract}
A well-designed and structured ADR system can be used as a strong tool to combat corruption effectively and eventually lead to successful conviction of it. The main objective of this study is to comparatively analysis the roles of ADR law in combating corruption in Ethiopia, Hong Kong and Rwanda in order to draw some best lessons and forwards the recommendations for the identified issues. To achieve the research objectives, the study employed the combination of comparative and doctrinal legal research approach. However, to substantiate the discussion and consolidate arguments, the paper also employed some relevant empirical data. Accordingly, the researcher has collected data through interviews selected purposively from FEACC, FPC and FAG. Then, the data were analyzed and interpreted to draw conclusions. Accordingly, the study reveals that Ethiopian ADR law has not comprehensively designed to combat corruption in Ethiopia as compared to the selected jurisdictions. As a result of these findings and on the basis of lessons drawn from the experiences of the selected countries, the article recommends different measures to be taken into account by the government, law enforcement and FEACC so as to enhance the effective implementation of ADR law in combating corruption in Ethiopia.

Keywords: Corruption, Assets Disclosure and Registration, Asset Declaration, Asset Disclosure, Public Officials,
\end{abstract} Transparency International.

DOI: $10.7176 / \mathrm{JLPG} / 95-02$

Publication date:March $31^{\text {st }} 2020$

\section{INTRODUCTION}

Corruption constitutes one of the most serious problems that the world is facing today. ${ }^{1}$ This phenomenon is found in all countries but it is in the developing world that its effects are most destructive. ${ }^{2}$ In this regard, Ethiopia is not exceptional to these issues. ${ }^{3}$

To avert corruption problems, various international and regional anti-corruption instruments and strategies are adopted and came in to force with the intention of preventing and combating corruption in a coordinated manner. Among other anti-corruption strategies, Assets Disclosure and Registration (ADR) scheme have been recognized internationally and regionally by anti-corruption instruments as a means of ensuring integrity in public office. ${ }^{4}$ For example, Article 8 of United Nations Convention against Corruption (UNCAC) addresses in general terms the need for states parties to ensure probity in public office. Specifically, Article 8(5) requires States Parties to establish systems that require public officials to declare, inter alia: "their outside activities, employment, investments, assets and substantial gifts or benefits. " Among regional anti-corruption instruments, Article 7(1) of the African Union Convention on Preventing and Combating Corruption (AUCPCC) also provides a similar requirement for public officials to declare their assets before, during, and after serving in public office. ${ }^{6}$ These Conventions accept the significant role that asset disclosure by public officials plays in combating corruption and related offences in the public service.

Ethiopia is a party to most international and regional anti-corruption instruments. It has signed and ratified $\mathrm{UNCAC}^{7}$ and the AUCPCC. ${ }^{8}$ These conventions urge states parties to require designated public officials to declare their assets regularly. To ensure its commitments under those conventions, the government of Ethiopia has

\footnotetext{
${ }^{1}$ Okechukwu I.Eme, et al, African Anti-Corruption Agencies: Challenges and Prospects, (Spring 2017) Management Studies and Economic Systems (MSES), 3(4) 225-243.

2 ibid.

${ }^{3}$ This can be evidenced from the Transparency International Corruption Perception Index.

${ }^{4}$ Inter-American Convention Against Corruption (IACAC), Mar. 29, 1996, 35 I.L.M. 724, Art.3; see African Union Convention on Preventing and Combating Corruption(AUCPCC), July11, 2003, 43 I.L.M. 5 , Art.7, para 1; see also United Nations Convention Against Corruption (UNCAC) (2003), Art. 8(5).

${ }^{5}$ UNCAC, Supra note 4, Art.8(5).

${ }^{6}$ AUCPCC, Supra note 4, Para 1, Art.7.

Ethiopia signed the Convention on 10 December 2003 and ratified it on 26 November 2007, available at https://www.unodc.org/documents/treaties/UNCAC/CountryVisitFinalReports/2015_10_14_Ethiopia_Final_County_Report.pdf accessed on 26 March, 2019.

8 The Convention was signed by Ethiopia on 1 June 2004 and ratified on 18 September 2007, available at https://www.unodc.org/documents/treaties/UNCAC/CountryVisitFinalReports/2015_10_14_Ethiopia_Final_County_Report.pdf accessed on 26March, 2019.
} 
promulgated Assets Disclosure and Registration (ADR) Procl.No.668/2010 in April 2010. ${ }^{1}$ Thus, the Ethiopian ADR law has intended to avoid possible conflict of interest and prevention of corruption as well as to assist in the detection, investigation, and prosecution of corruption. ${ }^{2}$

Even though Ethiopia has enacted ADR law and other anti-corruption laws, it is important to note that corruption acts persist as a pressing issue in Ethiopia. As per the Corruption Perception Index of Transparency International of 2018 , Ethiopia was ranked $114^{\text {th }}$ out of 180 countries with a score of $34 .{ }^{3}$ Any score below 50 on the Corruption Perceptions Index indicates serious levels of public sector corruption. Moreover, according to World Justice Project Rule of Law on 2019 Index, Ethiopia was ranked $118^{\text {th }}$ out of 126 countries with a score of $0.39^{4}$,where any score below 0.40 on rule of law index indicates weaker adherence to the rule of law. In contrast, one study noted that the effectiveness of the Ethiopian government in combating corruption has been increased and level of corruption perception index decreased at steady level post the enactment of ADR law and increased cleanness of corruption in the country. ${ }^{5}$ Therefore, the key question to be answered in this research is that whether Ethiopian ADR law has been adequately designed to battle corruption or not.

Against this backdrop, this article is intended to examine the roles of ADR law in combating corruption in Ethiopia in comparison with those selected jurisdictions. To meet its aims, the study combination of comparative and doctrinal legal research approach in utilizing both primary and secondary data sources. However, to substantiate the discussion and consolidate arguments, the paper also employed some relevant empirical data. Accordingly, the researcher is collected data through interviews selected purposively from FEACC (Federal Ethics and Anti-Corruption Commission), FAG (Federal Attorney General), and FPC (Federal Police Commission).

For comparative study, the legal framework of Hong Kong and Rwanda are selected for a comparison with Ethiopia based on the following reasons: First, Hong Kong and Rwanda has very low corruption levels and ranks the cleanest countries in the world. ${ }^{6}$ Second, Hong Kong and Rwanda has achieved considerable success in the implementation of their ADR system. ${ }^{7}$ Third, from its inception, Ethiopia has adopted Hong Kong's three-pronged approach to fight corruption, which incorporates investigation, prevention and education. ${ }^{8}$ Today, in Ethiopia, however, except prevention and education, the power to investigate and prosecute corruption crimes are transferred to FPC and FAG respectively. Fourth, Rwanda and Ethiopia are nominally multiparty democracies that hold regular election. ${ }^{9}$ Fifth, in the mid-1990s, Rwanda and Ethiopia ranked among the poorest nations in the world, with GDP per capital of less than USD 150 dollars. ${ }^{10}$ Yet, they are the two fastest growing economies in the whole of Africa. ${ }^{11}$ Sixth, Rwanda and Ethiopia are emerged from violent civil wars led by ideologically driven guerrilla groups. ${ }^{12}$

The remaining part of the article is organized as follows. Section two presents the general overview of ADR system. Based on the principles of effective ADR scheme and comparative experience, section three examines the roles of the Ethiopia's ADR law in combating corruption; identify its shortcomings and exploring the opportunities to strengthen the current Ethiopian ADR law. Finally, section four comes up with conclusion and the way forward.

\footnotetext{
${ }^{1}$ Corruption Crimes Proclamation, No. 881/2015,Negarit Gazeta, 21 ${ }^{\text {st }}$ Year No.36, Addis Ababa, $3^{\text {rd }}$ April, 2015, Art. 21(hereinafter referred to Corruption Crimes Proclamation).

${ }^{2}$ Assets Disclosure and Registration Proclamation No.668/2010, Negarit Gazeta, $16^{\text {th }}$ Year No. 18, Addis Ababa 12 ${ }^{\text {th }}$ April, 2010, Preamble and Art.13 (hereinafter, ADR proclamation).

${ }^{3}$ Tl, Corruption Perceptions Index, available at https://www.transparency.org/research/cpi accessed on 26 March, 2019.

${ }^{4}$ World Justice Project 2018-2019 Rule of Law Index, available at:

https://worldjusticeproject.org/sites/default/files/documents/WJP-ROLI-2019-Single\%20Page\%20View-Reduced_0.pdf accessed on 29 May, 2019. This Rule of Law Index is comprised of eight factors: Constraints on powers; Absence of corruption; open government; Fundamental rights; Order and Security; Regulatory Enforcement; Civil Justice; and Criminal Justice.

${ }^{5}$ Bekuretsion Alemayehu, 'A Study of the Role of Assets Disclosure and Registration Law Proclamation. No 668/2010 in Reducing Corruption: The Case of FEACC' (Unpublished MA thesis, AAU, 2015), at 112.

${ }^{6}$ As per Transparency International's Corruption Perceptions Index of the; 2016, 2017 and 2018, Hong Kong scored 77, 77 and 76 against a clean score of 100 in the years under consideration respectively and most taken as exemplary in fighting Corruption Crime; and 2016, 2017 and 2018, Rwanda scored 54, 55 and 56 against a clean score of 100 in the years under consideration respectively and most taken as exemplary in reducing corruption crimes.

${ }^{7}$ World Bank, 'Income and Asset Disclosure: Case Study Illustrations' (Directions in Development Washington, DC: World Bank, 2013), at 94.

${ }^{8}$ Federal Ethics and Anti-Corruption Commission of Ethiopia Anti-Corruption Authorities (ACAs) Portal.html, Last Updated: August 2012, available at https://www.acauthorities.org/country/et accessed on May 27, 2019.

${ }^{9}$ Hilary Matfess, 'Rwanda and Ethiopia: Developmental Authoritarianism and the New Politics of African Strong Men' (2015), Volume 58 / Issue 02 African Studies Review, 181-204.

10 Oliver Reynolds, Ethiopia and Rwanda: From Destruction to Development, (2018), available at: https://www.focuseconomics.com/blog/ethiopia-and-rwanda-from-destruction-to-development accessed on 27 May 2019.

11 Ibid.

${ }^{12}$ Gagliardone, I \&Golooba-Mutebi, F, 'The Evolution of the Internet in Ethiopia and Rwanda: Towards a "Developmental” Model? Stability' (2016): 5(1): 8 International Journals of Security \& Development, at 1-24.
} 


\section{ASSETS DISCLOSURE AND REGISTRATION SYSTEM: CONCEPTION, PURPOSES, AND MODELS}

\subsection{Conceptualizing Assets Disclosure and Registration System}

ADR has no commonly accepted and single definition. Since the term reflects the social, political, economical and cultural contexts in which it is being operated, its contents may vary from country to country and even within a country from time to time based on the changes in government anti-corruption policy. Despite this, there are attempts to define the term. For instance, Ivana M. Rossi et al defined the terms as:"A mechanism by which a public official must periodically submit information about his or her income, assets, liabilities, and/or interests." ADR also referred to as asset disclosure, income and asset declarations, wealth reporting, and interest declarations. Further, the terms refers to the entire process of disclosing assets, and interests, from the blank form to submission, verification, and sanctioning. ${ }^{2}$

ADR frameworks are not new. Its systems began to evolve into modern form after the Second World War. ${ }^{3}$ In the 1960s, due to corruption scandals in the places like the United States of America, Hong Kong and the Netherlands', governments changed its direction to ADR system as one mechanism of prevention of corruption. ${ }^{4}$ Following USA, the UK House of Commons introduced the register of interests in 1974, while other European countries followed suit with laws of their own in the early 1980s. ${ }^{5}$ The global number of ADR laws spiked dramatically in the 1990s as the cold war ended and a large number of countries in the former Soviet Bloc adopted new constitutions along with the newly-independent nation-states of Africa. ${ }^{6}$ As Vargas and Schlutz indicated, the ADR regulation has greatly expanded across all the country since 1996s to 2012s. ${ }^{7}$

In spite of growth both in the number of countries with ADR laws and in the role that disclosure plays in international efforts to fight corruption, it is worthy to note that ADR provisions have not always translated into effective systems. ${ }^{8}$ Thus, its implementation is often leaving a large gap between system "in law" and "in practice" in different countries. ${ }^{9}$

\subsection{Purpose of Assets Disclosure and Registration System}

The importance of the ADR system in fighting corruption is increasing day by day, through monitoring the development and changes of the public officials' wealth. As Burdescu et al rightly put, ADR can play two important roles within broader anti-corruption efforts: prevention, and law enforcement. ${ }^{10}$ In the preventive function, the ADR system seeks to prevent corruption through increasing the sense of responsibility and accountability to the public officials, where they are required to disclosed their assets and benefits periodically subject to sanctions in case of abstain to comply with it. ${ }^{11}$ Besides, the law enforcement role of the ADR is to assists the investigation and prosecution of corruption crimes as a source of information which will be easier to reveal the cover off the required information or data related the public official. ${ }^{12}$

\subsection{Models of Assets Disclosure and Registration System}

Many considerations should be taken into account in designing the ADR system. As Burdescu et al noted the scope of implementation, making balance between the public right to know and the right of privacy of individuals, how to control the monitoring of compliance and verification, budgetary and the qualified personnel are crucial to run the ADR system. ${ }^{13}$ Besides, designing according to objectives is also another major consideration on how to know which model can meet the size of corruption. ${ }^{14}$

Ironically, a model of ADR is determined depending on the legal framework and objectives of ADR systems. Thus, three main models worldwide have been identified. ${ }^{15}$ These are: the illicit enrichment, conflict of interest

\footnotetext{
${ }^{1}$ Ivana M. Rossi et al, 'Getting the Full Picture on the Public Officials: A How to Guide for Effective Financial Disclosure' (Stolen Asset Recovery (StAR) Series. Washington, DC:WB, 2017), at xix.

${ }^{2} \mathrm{Id}$, at 2 .

${ }^{3}$ Ruxandra Burdescu et al, 'Income and Asset Declarations: Tools and Trade-Offs' (Washington DC: World Bank 2009 ), at 28.

${ }^{4}$ WB \& UNODC, 'Asset and Income Declaration Guide Concept Note,' (2009), at 2.

${ }^{5}$ OECD, 'Fighting Corruption in Eastern Europe and Central Asia Asset Declarations for Public Officials: A Tool to Prevent Corruption Paris' (OECD Publishing, 2011), at 22.

${ }^{6}$ Ruxandra Burdescu et al, Supra note 23, at 28.

${ }^{7}$ Gustavo A. Vargas \& David Schlutz, 'Opening Public Officials Coffers: A Quantitative Analysis of the Impact of Financial Disclosure Regulation on National Corruption Levels' (2016), Eur J Crim Policy Res 439-475.

${ }^{8}$ Ibid.

${ }^{9}$ Ibid.

${ }^{10}$ Ruxandra Burdescu et al, Supra note 23, at 6.

${ }^{11}$ Barnes DW et al, 'Public Office, Private Interests: Accountability through Income and Asset Disclosure'(Washington DC: World Bank 2012), at 7.

${ }^{12}$ Mohannad Ahmad et al, 'The Law onthe Illicit Enrichment Crime and Financial Disclosure in Jordan: Issue of Effectiveness and Enforceability (2016),' Vol. 2, No. 5 The Journal of Social Sciences Research, at 98-110.

${ }^{13}$ Ruxandra Burdescu et al, Supra note 23, at 7-8.

${ }^{14}$ Barnes DW et al, Supra note 31, at 9 .

${ }^{15}$ Ivana M. Rossi et al, Supra note 21, at 9-10.
} 
and the mixed model. Illicit Enrichment Model is primarily focus on the prevention, detection, investigation or prosecution of illicit enrichment. ${ }^{1}$ In this system, declarations are planned to capture information that will enable the tracking of an official's wealth to detect any unusual assets or income not attributable to salary or other legitimate source. ${ }^{2}$ Conflict of Interest Model is a sort of warning or caution to conflict of interest. It offers assistance to avoid situations which may lead to such conflict and to ensure that the filler is not subjected to accusations or suspicions of bias or corruption. ${ }^{3}$ The third model is combination of illicit enrichment and conflict of interest models. That is to say, it has the preventive role side-by-side with the law enforcement of detection of illicit enrichment. Thus, it aims to reduce the conflict of interest and detecting the wealth of public officials, join the investigation and assist prosecution of the corruption crimes.

\section{ELEMENTS OF AN EFFECTIVE ASSETS DISCLOSURE AND REGISTRATION LAW IN COMBATING CORRUPTION IN ETHIOPIA: A COMPARATIVE ANALYSIS WITH THE HONG KONG AND RWANDA LEGAL SYSTEMS}

As discussed previously, assets declarations by public officials and civil servants have got a great attention in anticorruption literature by international, regional, and local organizations. Many countries have also adopted laws and regulations which require public officials and civil servants to declare their asset and liabilities either upon entry into the public service or promotion into a position with potential for corruption or upon termination. While scholars and organizations have identified several core elements that should be at the center of any ADR system, each ADR system must be tailored to the specific country that it serves and must engage local and national stakeholders to support reforms and ensure sustainability, since there is no internationally recognized standard of practice. ${ }^{4}$ The OECD recommends that countries take into account their legal traditions and past experiences, and evaluate current issues to determine the legal approach to assets declaration which most likely will generate support among politicians, public officers and the general public..$^{5}$

Despite this, there are, as yet, no specific international standards detailing how ADR regimes are best designed, implemented and monitored. ${ }^{6}$ Over the last decade, however, an emerging consensus has identified several core principles for the establishment of effective ADR mechanisms. ${ }^{7}$ Accordingly, consistent with international standards and the preventive measures for governments outlined in Chapter III of the UNCAC, Transparency International identified the following core principles for an effective and legally based ADR system based on its previous publications in this area. ${ }^{8}$ These principles are: (a) Clear Objectives; (b) Coverage of Public Officials; (c) Content and Comprehensiveness of Declarations; (d) Filling Frequency and Submission of Declarations; (e) Verification Mechanisms ; (f) Public Access; and (g) Enforcement and Sanction. ${ }^{9}$

Within these basic elements, the Ethiopian ADR proclamation will be analyzed in comparison with the Hong Kong and Rwanda's ADR Laws as follows.

\subsection{Objectives of Assets Disclosure and Registration System}

The initial step in the establishment of an effective ADR regime is to define clearly its aims and objectives. ${ }^{10}$ Without having clear objectives of the system, it will go down into ineffectiveness. ${ }^{11}$ The immediate objectives of ADR system are specific to each country; thus, each system is designed differently. ${ }^{12}$ Although there may be a variety of objectives, ADR system would be directed mainly at combating illicit enrichment, or at identifying and preventing conflict of interest, or at both of these objectives. ${ }^{13}$ Here under, the designated objective of the regime also determines the human resources that are allocated for its implementation. ${ }^{14}$

ADR system with the primary goal of preventing illicit enrichment emphasizes means of monitoring a public officer's wealth. Its focus, therefore, is on strengthening the verification of the declaration with the aim of detecting any hidden assets. ${ }^{15}$ For instance, the ADR system in Rwanda is designed solely to prevent, detect, and prosecute

\footnotetext{
${ }^{1}$ Barnes DW et al, Supra note 31, at 14 .

${ }^{2}$ Ivana M. Rossi et al, Supra note 21, at 14.

${ }^{3}$ Barnes DW et al, Supra note 31, at 9.

${ }^{4}$ OECD, Supra note 25.

${ }^{5} \mathrm{Id}$, at 15 .

${ }^{6}$ Barnes DW et al, Supra note 31, at 16-17.

${ }^{7}$ Matthew Jenkins, 'Income and Asset Disclosure Topic Guide Compiled by the Anti-Corruption Helpdesk ,Transparency International," (2015).

${ }^{8}$ Transparency International, 'Asset Declarations in Morocco: Illicit Enrichment and Conflicts On of Public Officials,' (2015), at 3-4

${ }^{9}$ Ivana M. Rossi et al, Supra note 21.

${ }^{10}$ Ruxandra Burdescu et al, Supra note 23, at 6.

${ }^{11} \mathrm{Id}$, at 6.

${ }^{12}$ Ivana M. Rossi et al, Supra note 21, at 10.

${ }^{13}$ Ruxandra Burdescu et al, Supra note 23, at xi.

${ }^{14} \mathrm{Id}$, at 8 .

${ }^{15}$ Barnes DW et al, Supra note 31, at 14.
} 
illicit enrichment. ${ }^{1}$ As Barnes DW noted, ADR are routinely and systematically used as one of the investigatory tools during illicit enrichment crime investigation in Rwanda. ${ }^{2}$ Further, he indicated that assets stored in the archives, is also ready to be used by the police or the Office of the Prosecutor General during illicit enrichment crime investigation. ${ }^{3}$

In Hong Kong, the ADR system initially focused solely in detecting, investigating and prosecuting illicit enrichment crime committed by public officials and civil servants. ${ }^{4}$ Accordingly, it is one of the primary tools used by the Independent Commission Against Corruption (ICAC), particularly during the 1970s and 1980s, in the investigations and prosecutions of possession of unexplained property crime based on section 10 of the Prevention of Bribery Ordinance (POBO). ${ }^{5}$ Later on, however, the ADR system in Hong Kong is focused solely on the identification and prevention of conflicts of interest for public employees and public officials. ${ }^{6}$ It complements, but does not replace, the work of the ICAC aimed at uncovering and prosecuting illicit enrichment through the use of section 10 of the POBO. ${ }^{7}$

Unlike Hong Kong and Rwanda's experiences, it is clear that Ethiopia's ADR law adopted both illicit enrichment and conflict of interest purposes. ${ }^{8}$ The main objectives of the enactment of ADR law by Ethiopian government is with a view to making transparency and accountability basis for government operation, preventing corruption, ensuring the prevalence of good governance and creating a mechanism by which conflict of interest can be avoided and a clear line can be drawn between official authority and private interest. ${ }^{9}$ However, it must be understood that Ethiopia is being facing huge challenges in achieving both these purposes of assets declarations due to lack of skilled and experienced expertise in the areas of receiving, verifying and maintaining ADR scheme. ${ }^{10}$ This raises indeed the question; whether primary focus on illicit enrichment or conflict of interest objective of ADR law is most fit current corruption problems in Ethiopia and whether there is a good trend to be adopted from the selected jurisdictions.

Of course, deciding on either purpose is difficult. Thus, the objectives of the ADR system depend on several factors such as the socio-economic and political situations of Ethiopia. Hereunder, I will suggest that Ethiopia needs to take lesson from Rwanda that would fit to the realities of the country. Some research reveals that a primary or even exclusive focus on illicit enrichment in ADR system is preferable in countries or sectors where there are high levels of perceived corruption and impunity. ${ }^{11}$ Ethiopia score of 34 on the 2018 Corruption Perceptions Index show very high levels of perceived corruption. ${ }^{12}$ So, a primary focus on illicit enrichment in ADR system I am advocating for Ethiopia to be derive trend from Rwanda should take into account these factors. To adopt Hong Kong experience that primary focus on conflict of interest in ADR scheme will not viable for the reasons that are rampant corruption in Ethiopia. As compared to intensity of the corruption in Ethiopia, primary focusing on conflict of interest to prevent corruption is like adding water droplets into the ocean. Akin to Rwanda, therefore, Ethiopia should hardly work on the primary focus of illicit enrichment purposes of ADR so as to prosecute corrupt officials.

\subsection{Subjects of the Assets Disclosure and Registration System}

There is no standardized list of public officials and civil servants who should declare assets. ${ }^{13}$ The type and rank of officials and civil servant subject to the asset disclosure obligation varies from country to country, with each mode necessarily making a number of compromises in terms of cost and benefits. ${ }^{14}$ While some countries prefer to restrict (narrower coverage) the declaration requirement to senior office holders or those in sensitive positions, others require the declaration of assets of less senior officials more generally, with some also requiring information about the assets of officials' spouses. Only a few countries, however, require asset declaration of public officials and civil servants at all levels (broader). ${ }^{15}$ The rationales for a broader disclosure mandate in which most or all public officials and civil servants are required to declare include, among others, the possibility that corruption may

\footnotetext{
${ }^{1}$ World Bank, Supra note 15, at 174.

Ibid.

${ }^{3}$ Ibid.

${ }^{4}$ Messick Richard, 'Income and Assets Declarations: Issues to Consider in Developing a Disclosure Regime 1,” (2009), at 13.

${ }^{5}$ World Bank, Supra note 15, at 88.

${ }^{6} \mathrm{Id}$, at 82 .

${ }^{7} \mathrm{Id}$, at 89 .

${ }^{8}$ ADR Proclamation, Supra note 10, Preamble \& Art.13.

${ }^{9}$ Ibid.

${ }^{10}$ Interview with Andualem Tamene, Senior assets verification expert and Team leaders of Asset Disclosure and Registration Directorate at the FEACC, Done at his Office, 7 June, 2019; Interview with Bogale Taso, Senior Declaration Officer and Team leaders of Assets Disclosure and Registration Directorate at the FEACC, Done at his Office, 7June, 2019; Federal Ethics and Anti-Corruption Nine Month Performance Report, 2018/2019 (FEACC Nine Month Performance Report, 2018/2019), at 28.

${ }^{11}$ Ruxandra Burdescu et al, Supra note 23, at 6.

12 Transparency International Corruption Perceptions Index (2018).

${ }^{13}$ OECD, Supra note 25, at 16; see also Ivana M. Rossi et al, Supra note 21, at 19.

${ }^{14}$ Ibid; see also Barnes DW et al, Supra note 31, at 34-37.

${ }^{15}$ Marie Chene, 'African Experience of Asset Declarations', (U4 helpdesk Transparency International 2008 ), at 3.
} 
occur at all levels of public service, and the desire to send a strong message to society about efforts to promote transparency. ${ }^{1}$ However, there is a concern of high cost of administration if the system is to be run effectively or lack of effectiveness if the resources needed are not provided. ${ }^{2}$ Further, there is a concern that it can produce very detailed information which intern result difficult and time-consuming to process and monitor. ${ }^{3}$

When we look into the experiences of Hong Kong, it has been adopted tiered approach classification of public officials and civil servants obligated to file assets. ${ }^{4}$ Accordingly, in Hong Kong, government employees are categorized into three tiers. ${ }^{5}$ Under Civil Service Bureau (CSB) rules of Hong Kong, those public officials and civil servants designated as Tier I and Tier II are required to declare their investments because of heightened risk of exposure to potential conflict of interest situations and illicit enrichment. ${ }^{6}$ But, Tier III public officials and civil servants are not required to declare their assets on a regular basis.

On contrary, Rwanda has specified somehow a broader coverage of the public officials and civil servants subject to income and asset declaration law. Specifically, Article 4(4) of that law requires the president, members of parliament, ministers, defense forces, national police, judges, prosecutors, judicial police officers, certain highranking civil servants, and the spouses and children under18 years of age of each of those individuals to declare their income and assets. ${ }^{7}$

Similar to the trend of Rwanda, Ethiopia's ADR law has also covers broader range of any appointee, elected personal or public servants subject to register and disclose their assets. ${ }^{8}$ In the definitional part of the proclamation, the term appointees, elected persons and public servants are defined. ${ }^{9}$ The legislative, executive and judicial organ officials; public servants and officials of public enterprise are under a duty to register and disclose their assets. Further, the above mentioned persons are obligated to register and disclose their assets "under their ownership or possession of themselves or their families and the sources of income and those of their families" ${ }^{10}$ However, common property acquired through inheritance and held by the heirs for private use, household goods and personal effects, and pension benefits are excluded from registration and disclosure. ${ }^{11}$

As mentioned above, the ADR proclamation covers a wide range of appointees, elected persons and public servants; and thereby has an impact in safeguarding public confidence in the conduct of public affairs in Ethiopia. Requiring wider an appointee, elected person or a public servant to declare their asset in Ethiopia, however, is experiencing difficulties in handling, verification and monitoring of the declarations due to lack of resources and capacity, leading to the ADR system being implemented poorly. ${ }^{12}$ Here under, Ethiopia needs to reconsider carefully the costs and benefits of a broader or narrower coverage. The experience of Hong Kong is very important as it target public officials and civil servants who hold position of high-level. Therefore, Ethiopia needs to derive this trend of Hong Kong and should reconsider the scope and coverage of public officials and public servants subject to her ADR law.

\subsection{Contents of Assets Disclosure and Registration System}

There is no uniform standard of information that should be declared, but it is important to note that ADR system should contain broad range of all income and assets in order to provide a comprehensive picture of a public officials and civil servants financial situation. ${ }^{13}$ The level of detail required in the declaration form depends on the capacity of the responsible institutions to handle the information properly.$^{14}$ However, most declaration forms require a combination of the following categories of information: immovable and movable assets, liabilities, financial and business interests, positions outside of office, and information on the sources and values of income. ${ }^{15}$ Thus, any

\footnotetext{
${ }^{1}$ Ivana M. Rossi et al, Supra note 21, at 19.

${ }^{2}$ OECD, Supra note 25, at 52.

${ }^{3}$ Marie Chene, Supra note 65 , at 3

${ }^{4}$ World Bank, Supra note 15, at 84-85. It is an approach that is to target public servants who hold position of high-level and it is based on the assumption that high - ranking public officials may have more discretion and authority to abuse public office.

${ }^{5}$ Ibid 85; Tier I includes key government positions, including permanent secretaries, the commissioner of police, the commissioner of the ICAC, the director of immigration, the commissioner of customs and Excise, the Director of audit posts, and the head of the Central Policy Unit; Tier II includes administrative assistants who support Tier I posts, all director posts, and any other posts designated by permanent secretaries according to their risk of exposure to potential corruption acts; and Tier III posts include all other positions in the government or which includes all civil servants not included in the first two tiers.

${ }^{6}$ CSB Circular No.8/2006, No.8/2006, Hong Kong SAR, China.

${ }^{7}$ Law No. 76/2013 of 11/9/2013 Determining its Mission, Powers, Organization and Functioning, Official Gazette $n^{\circ}$ Special of $18 / 10 / 2013$, Art.4,(hereinafter, Law on Determining the Ombudsman's Office Mission, Powers, Organization and Functioning )

${ }^{8}$ ADR Proclamation, Supra note 10, Art. 4.

${ }^{9}$ Id, Art. $2(4,5,6)$

${ }^{10} \mathrm{Id}$, Art.4(1).The Proclamation under Art. 2(8) defines 'family' to include 'spouse, dependent child under the age of 18, adopted children and spouse in irregular union'

${ }^{11} \mathrm{Id}$, Art. 5

${ }^{12}$ Interview with Andualem Tamene, Supra note 60 ; Interview with Bogale Taso, Supra note 60.

${ }^{13}$ Ivana M. Rossi et al, Supra note 21, at 33.

${ }^{14}$ Barnes DW et al, Supra note 31.

${ }^{15}$ Ivana M. Rossi et al, Supra note 21, at 33; see also OECD, Supra note 25, at 62-5.
} 
credible ADR regime needs to express clearly what assets, liabilities and interest of public officials and civil servants must personally declare. In addition to personal and business, assets disclosure considered good practice for public officials and civil servants to disclose assets and income of spouse and children. ${ }^{1}$

Some jurisdictions require different levels of disclosure for different categories of public officials and civil servants, whereas others do not. In Hong Kong, for example, holders of Tier I and Tier II positions are required to declare any investment, shareholding, or indirect interest in any company or undertaking, and any interest in land or building (including one's home) in Hong Kong, and abroad. ${ }^{2}$ Further, both levels of public officials and civil servants must also declare their spouse's occupation. However, Tier III officials are not required to declare their assets on a regular basis but are required to disclose potential conflicts of interest and to avoid conflicts of interest. ${ }^{3}$

In sharp contrast to the Hong Kong experience, both Rwanda's and Ethiopia's ADR regime requires all covered public officials and civil servants declare their immovable and movable assets, liabilities, and all income as well as to disclose their spouse and children assets and income. ${ }^{4}$

When we see the Ethiopian ADR law from perspectives of contents of declaration element in combating illicit enrichment crime, it leaves some margin of doubt or concerns. The first problem is that Article 4(1) of ADR proclamation simply requires an appointee, elected person or a public servant to declare their assets and source of income and those family members for FEACC but it fails to require proof that assets registered by filer were not acquired illicitly. ${ }^{5}$ On top of that, the law lacks clarities as to whether it would prevent an appointee, elected person or a public servant to over-declare his or her assets in anticipation that he or she would during his or her tenure in office acquire, through corrupt activities, assets the equivalent of what has been declared or not. Therefore, this gap in the law gives any appointee, elected person or public servant the chance for validating illicitly obtained properties as legitimate. That is to say, this lacuna in the law is prone to abuse, as targeted public officials and civil servants can fake declarations without being detected. The second apparent problem is that, the ADR proclamation does not require an appointee, elected person or a public servant to declare the assets and income of their children above the age of 18, close relatives and others persons. In such a case, the possibilities of hide and the transfer of illegally obtained property to other persons are likely to be increase. Another third problem is with regards to determine the current market value of assets in monetary figures. The Ethiopian ADR form generally request an appointee, elected person or a public servant to provide the market value of assets based on their own beliefs rather than on current market value. ${ }^{6}$ Hence, under this lacuna, there might be a probability for manipulation and artificial increase in the price of the property.

In general, all the above raised gaps and loopholes in law disable the real objectives of the ADR law in combating corruption in Ethiopia. So, it is noteworthy that ADR regime should be precise on the details of information to be declared and to leave no room for confusion and uncertainties. Lack of clarity about what an appointee, elected person or a public servant is to be disclosed threatens the effectiveness of ADR system. ${ }^{7}$

\subsection{Filing Frequency}

Filing frequency is a crucial element of a well-designed ADR system. The frequency with which assets declarations must be made will depend upon a number of factors such as the need for up-to-date information, the avoidance of over-filing and the risk of non-compliance. ${ }^{8}$ Importantly, filing frequency must ensure that the information regarding public officials and civil servants wealth remains current and promotes the effectiveness of the system in detecting illicit accumulation of wealth. However, when the agency determines the required filing frequency, it should also take into account finance, human and material resource and the responsibilities of various public officials and civil servants so as to be able to administer the declaration effectively and efficiently. ${ }^{9}$ Thus, there should be a balance between the number of public officials and civil servants obliged to declare their assets and the capacity of the agency to receive and monitor these declaration; otherwise, the process becomes only a formality.

The frequency of submission varies from one country to another which could be periodically, annually, or every two years. ${ }^{10}$ That is to say, there is no perfect time for frequency of filing. However, a review of some of the literature showed that several countries made provision for filing entering office, at the end of every one year and

\footnotetext{
${ }^{1}$ OECD, Supra note 25, at 14.

${ }^{2}$ World Bank, Supra note 15 , at 85

${ }^{3}$ Ibid

${ }^{4}$ Law No. 76/2013 of 11/9/2013 Determining its Mission, Powers, Organization and Functioning, Official Gazetten ${ }^{\circ}$ Special of $18 / 10 / 2013$, Art.4,(hereinafter, Law on Determining the Ombudsman's Office Mission, Powers, Organization and Functioning ),Art.4(4), 37 \& 38; see also ADR proclamation, Supra note 10, Art. 4(1).

${ }^{5}$ ADR Proclamation, Supra note 10, Art. 2 \& 4(1)

${ }^{6}$ Federal Ethics and Anti-Corruption Commission, Assets Disclosure and Registration Form, April, 2010 E.C.

${ }^{7}$ Marie Chene, Supra note 65, at 2.

${ }^{8}$ Ruxandra Burdescu et al, Supra note 23, at 37; see also Messick Richard, Supra note 54, at 11

${ }^{9}$ OECD, Supra note 25, at 68.

${ }^{10}$ Messick Richard, Supra note 54, at 12.
} 
upon leaving office. ${ }^{1}$

As indicated above, the frequency of filing differs from one country to another depending on their ADR system. In Hong Kong, for example, officers holding Tier I positions are required to declare upon appointment and annually as well. Whereas holders of Tier II post are required to declare upon appointment and biennially thereafter. ${ }^{2}$ Further, Hong Kong has established a central online service through which declarations are collected. ${ }^{3}$

On the other hand, in Rwanda, covered public officials and civil servants must file annually as well as upon taking office and leaving government office. The legislation determining the Mission, Powers, Organization and Functioning of the Office of the Ombudsman requires that disclosure statements be filed within a period of one (1) month from the date of taking office; not later than 30 June each year; and within a period not exceeding fifteen (15) days from the date they left office for those who are no longer in public service. ${ }^{4}$ Akin to Hong Kong, Rwanda has also implemented online portal for the electronic submission of declarations. ${ }^{5}$

However, unlike the experiences of Hong Kong and Rwanda, Ethiopia requires an appointee, elected person or public servant to make a declaration every two years within 30 days from the end of the budget year. ${ }^{6}$ Within these two years' time if there are things which are inconsistent in the financial life of an appointee, elected person and public servant, they should explain it otherwise it can be a crime by holding unexplained property. ${ }^{7}$ Even in times when the generated illegal income or asset may not by provable, the disclosure of information can be used as a separate vehicle for the detection of illicit enrichment and contribute to investigation and disciplinary procedures. ${ }^{8}$ Furthermore, the proclamation requires any an appointee, elected person or a public servant to make a disclosure within forty five (45) days following his appointment, election or employment'; and within one month (30 days) from the date of his retirement or termination or service and finally to the FEACC after two (2) years. ${ }^{10}$ Making mandatory declaration for those individual leaves her or his position after two (2) years under the proclamation is important to capture deferred illicit enrichment. However, there may be a concern with regard to determine the period of interest of illicit enrichment crime. Under Ethiopia ADR proclamation, there is no mandatory asset disclosure and registration provided as a prerequisite for any an appointee, elected person or a public servant before occupying a position and before leaving office. In such instances, it is difficult and invisible to identify acquired property before or during or after assuming power by these persons under control in detecting, investigating, and prosecuting crime of illicit enrichment. ${ }^{11}$

In comparison to the experiences of Hong Kong and Rwanda, Ethiopia's trend that every two years frequency of filling, while an appointee, elected person and a public servant is in office, should be maintained and commendable in view of the limited resources (financial, human and material) so as to be able to administer the declaration effectively and efficiently. In the opinion of the writers of this article, that requiring disclosure statements from an appointee, elected person and a public servant annually while he or she is in office, seems superfluous if juxtaposed to the fact of socio-economic and political factors of Ethiopia. So, this every two years frequency of filing is a fairly standard in Ethiopia's context. Having this in mind, what Ethiopia should learn from both Hong Kong and Rwanda is that the use of technologies to underpin the effectiveness and efficiency of ADR system. Technologies are very powerful means to reduce errors; requires fewer staff; easy to submit and verify the process; spend less time to file in and submission; increase compliance rate; low cost; encourage public access, and more convenient to track and report the performance of agency in charge of ADR system. ${ }^{12}$ Therefore, this can be a good lesson to be drawn for Ethiopia.

\subsection{Verification of Assets Disclosure and Registration System}

Verification is the process by which the content of disclosure is reviewed to detect illicit enrichment, inconsistencies, red flags, potential conflict of interest, and other problems. ${ }^{13}$ It is a crucial rule, as it ensures the truthfulness of the information. Specifically, in the jurisdictions where corruption is high and the accountability of public officials is low, verification of declared information for the purpose of identifying false reporting and illicit

\footnotetext{
${ }^{1}$ Ivana M. Rossi et al, Supra note 21, at 26; see also OECD, Supra note 25, at 68.

${ }^{2}$ World Bank, Supra note 15 , at 86

${ }^{3}$ Id, at 70 .

${ }^{4}$ Law on Determining the Ombudsman's Office Mission, Powers, Organization and Functioning, Supra note 95, Art. 37.

${ }^{5}$ World Bank, Supra note 84, at 174.

${ }^{6}$ ADR Proclamation, Supra note 10, Art.7(3).

${ }^{7}$ Id, Art. 13.

${ }^{8}$ Berihun Adugna Gebeye, 'The legal Regime of Corruption in Ethiopia: An Assessment from International Law Perspective:' (Vol.4, No.1), Oromia Law Journal 73-124.

${ }^{9}$ ADR Proclamation, Supra note 10, Art.7(2).

${ }^{10}$ Id, Art. 10 .

${ }^{11}$ Worku Yaze Wadago, 'Criminalization of Possession of Unexplained Property and the Fight Against Public Corruption:' Identifying the Elements of the Offence under the Criminal Code of Ethiopia (2014), Vol. 8, No.1 Mizan Law Review 60.

${ }^{12}$ Mears Samnang Kuy, 'The Magic Bullet to fight Corruption through Income and Asset Disclosure (IAD)( Working Paper: 2014) 4

${ }^{13}$ Ivana M. Rossi et al, Supra note 21, at 67.
} 
enrichment crime is important. ${ }^{1}$ It is not only an extremely crucial aspect of ADR systems, but also most challenging and complex part of the asset monitoring process. ${ }^{2}$ Without such means of verification, public officials may not submit accurate information, without being exposed, thereby futile the main objectives of obtaining a genuine account of a public officials and civil servants wealth and income and an outline of interests. ${ }^{3}$

However, verification of all number of submitted declations is not feasible in terms of resources, time, and availability of staff members and their skill level. ${ }^{4}$ Hence, there are different approaches towards selecting the sample of declarations that will be verified for accuracy of the information submitted. Accordingly, many authors outline the following approaches that can be employed in the verification process: randomly selected sample; target (high-risk based on sectors, functions and tiered only high- ranking officials); red flags associated with variations of assets and income across time; referral from another agency; complaint or allegation regarding the legitimacy or accuracy of declared assets; media reports; and when public official is under investigation for corruption crimes. ${ }^{5}$ Some countries choose one of these approaches where as others make a combination of them.

As far as the methods for verifying the accuracy of declarations are concerned, it vary between countries but often include: checking declarations for internal consistency; comparing the official's disclosures to monitor changes over time; cross-checking with information held by other public entities; cross-checking with information held by other private entities; requesting clarifications or documents from the public officials and civil servants that are necessary to complete verification; and lifestyle checks to ensure the public officials and civil servants lives according to the declared means(through onsite visits to their home). ${ }^{6}$

In Rwanda, verification of declarations is explicitly required by law No. 76/2013 of 11/9/2013.

The experience in Rwanda show that, the Office of the Ombudsman identifies which declarations to verify by targeting a portion of filers based on their position and randomly chooses a sample of declarations to verify. ${ }^{8}$ In Rwanda, the verification method is also rigorous and in depth in order to determine whether an income and asset declaration is accurate. ${ }^{9}$ Thus, it check for internal consistency within one declaration; compare over time two or more declarations from the same filer; cross-check declarations with external records, and conduct lifestyle checks and house visits. ${ }^{10}$ If any large changes in wealth occur or the auditor believes the discrepancy suggests there is underlying criminal behavior being hidden, a full illicit enrichment crime investigation may be launched. ${ }^{11}$

As opposed to the trend of Rwanda, in Hong Kong, both the CSB and the Corruption Prevention Department does not actively verify the accuracy of submitted asset declarations. ${ }^{12}$ Rather, it places emphases on helping civil servants to avoid conflicts of interest. However, in situations where criminal investigation is underway or where a complaint has been raised, verification of the information provided in assets disclosure forms will be executed. ${ }^{13}$ In these cases, the ICAC may check the contents of the declaration.

In case of Ethiopia, the FEACC has been granted the mandate to verify the information submitted where it has sufficient ground to suspect the submission of incomplete, inaccurate or false information or where information is received on the inaccuracy of the registration or a criminal investigation is underway. ${ }^{14}$ Further, the FEACC may, in the course of verification process, require the concerned an appointee, elected person or a public servant to produce additional information and clarification of the issue; order any bank, financial institution or any other person having information regarding the assets of the concerned an appointee, elected person or a public servant to furnish such information; and avail itself of the professional assistance of the Auditor General or any other relevant body. ${ }^{15}$

In Ethiopia, unlike the experience of Rwanda which implements the combination of target and random sample approaches to verify declaration, only random sample verification is applicable in practice. ${ }^{16}$ Moreover, in Ethiopia, there is no practice of lifestyle checks and house visits. ${ }^{17}$ Therefore, Ethiopia should import the good experience

\footnotetext{
${ }^{1}$ Maira Martini, 'Asset declaration Regime in Selected Asian Countries', Transparency International and Anti-Corruption Resources Centre (2013), available at: www.u4.no/publications/asset-declaration-regimes-in-selected-asiancountries/ accessed on 25, March, 2019.

${ }^{2}$ Ruxandra Burdescu et al, Supra note 23, at 74.

${ }^{3}$ OECD, Supra note 25, at 71; see also Ruxandra Burdescu et al, Supra note 23, at 42.

${ }^{4}$ Barnes DW et al, Supra note 31, at 78; Ivana M. Rossi et al, Supra note 21, at 70.

${ }^{5} \mathrm{Id}$; see also OECD, Supra note 25 , at 71.

${ }^{6}$ Barnes DW et al, Supra note 31 , at 61.

${ }^{7}$ Law on Determining the Ombudsman's Office Mission, Powers, Organization \& Functioning, Supra note 84, Art.4(5)

${ }^{8}$ World Bank, Supra note 15, at 174.

${ }^{9} \mathrm{Id}$; According to the World Bank research of 2012, the Office of the Ombudsman verifies approximately $6 \%$ of the declarations it receives each year.

${ }^{10}$ Ibid.

${ }^{11} \mathrm{Id}$, at 183 .

${ }^{12} \mathrm{Id}$, at 86

${ }^{13}$ Id, at 92

${ }^{14}$ ADR Proclamation, Supra note 10, Art.11(1)

${ }^{15}$ ADR Proclamation, Supra note 10, Art.11(2).

${ }^{16}$ Interview with AndualemTamene, Supra note 60.

${ }^{17}$ Ibid; Interview with Zelalem Fekadu, Principal public Prosecutor and Prosecution Corruption Crime of Illicit Enrichment and Money Laundry coordination at the FAG, Done at his Office, 12 June, 2019. ; Interview with Woldemikael Fitora, Deputy Director of Corruption
} 
of Rwanda which carries out lifestyle checks and house visits, and the combinations of target and random sample as part of its standard verification approach to detect corruption.

\subsection{Public Access to Assets Disclosure and Registration System}

Public disclosure or accessibility refers to the provision which allows public at large to access information on compliance. ${ }^{1}$ Public disclosure may be full or limited disclosure. ${ }^{2}$ Whatever so, the credibility of ADR system has been related partly to the amount of access that members of the wider public have to them. ${ }^{3}$ Thus, public access allows the public to scrutinize the declaration, giving investigative journalists, media, scholars and civil society groups an opportunity to become engaged in monitoring the accuracy of public officials and civil servants assets through photos, public registers and interviews with neighbours and tenants. ${ }^{4}$ Unless public officials and civil servants declarations are made accessible to the wider public in a timely manner, the media, civil society and interested citizens will not be able to scrutinize such declaration and support law enforcement. Therefore, in such way, public accessibility can reinforce scrutiny. ${ }^{5}$

Public accessibility can increase the deterrent effect of disclosure systems. ${ }^{6}$ That is to say, public access not only assists detection of irregularities but also can add a layer of public shame for the wrongdoer. ${ }^{7}$ Having the knowledge that the declarations they make will be disclosed, public officials and public servants are more likely to comply with the requirements of the ADR system and are less likely to lie for fear of being found out through public scrutiny of their declarations. ${ }^{8}$ Furthermore, some studies have shown that public access to declare information is associated with lower levels of perceived corruption. ${ }^{9}$ Country experiences also indicate that public access can greatly increase the ability of disclosure systems to deliver results.

However, in many countries privacy laws may offer challenges for granting public access to declaration. ${ }^{10}$ With regard to this issue, the author will discuss in the next chapter four of this research.

Not all countries have the same approach towards public accessibility of declared information. Some countries opted to make the declarations of only certain high ranking public officials and civil servants public. In Hong Kong, for example, the declarations of high-level of public officials and civil servants are made public, while those of low-level officials and civil servants are kept confidential. ${ }^{11}$ Besides, asset declarations of high-ranking public officials and civil servants are available online, via websites of CSB. ${ }^{12}$ The justification for this is that these persons have opted to expose themselves to greater public scrutiny because they are more likely to be in positions that would allow them to significantly influence policies or divert public funds for personal gain. ${ }^{13}$ Therefore, making their declarations publicly accessible is a justifiable component of this scrutiny.

Others countries firmly embraced confidentiality for public officials and civil servants. For instance, Rwanda's ADR law ensures complete confidentiality of asset declarations to protect the privacy of filers except by court or prosecutor order for the investigation purposes. ${ }^{14}$ Despite declarations are available, thereby precluding a chance for civil society to hold public officials and civil servants accountable through the ADR framework, Rwanda has tried to built effective governmental mechanisms for contents verification and prosecution of corrupt activities. ${ }^{15}$ As discussed previously, Rwanda has been used declarations in the course of an investigation into an underlying crime, or when suspicious findings arise. However, there may be concerns that complete confidentiality of ADR system can severely undermine the capacity of the public sector to address illegal enrichment by government officials and employees by making it extremely difficult to use those declarations to identify potential problems. ${ }^{16}$

In another case, some other countries have adopted hybrid schemes to balance public disclosure with the need

Crimes Investigation Directorate at FPC, Done at his Office, 7June, 2019.

${ }^{1}$ OECD , Supra note 25, at 86.

2 Ibid; Full Public Disclosure means that all information provided in the declaration is made available for open public scrutiny. Limited disclosure is where certain categories of data are exempt from disclosure.

${ }^{3}$ Mukherjee \& Gokcekus, 'Officials Asset Declaration Laws: Do They Prevent Corruption?'(Transparency International Global Corruption Report 2006), at 325-328.

${ }^{4}$ Marie Chene, Supra note 65, at 5; see also Barnes DW et al, Supra note 31, at 84.

${ }^{5}$ Ivana M.Rossi et al , Supra note 21, at 90.

${ }^{6}$ Ibid.

${ }^{7}$ Ibid.

${ }^{8}$ Ellen Chiyamiko Chapita, 'The Law of Assets Declaration in Malawi' (Unpublished LL.M Thesis, University of the Western Cape, Faculty of Law, 2015), at 36.

${ }^{9}$ Mukherjee \& Gokcekus, Supra note 123, at 327.

${ }^{10}$ Barnes DW et al, Supra note 31, at 90.

${ }^{11}$ Ibid; see also World Bank, Supra note 15, at 87; Asset declarations of all Tier I officials are required to be made available to the public; while declarations of Tier II officials are confidential.

${ }^{12}$ Ivana M. Rossi et al, Supra note 21, at 80; see also World Bank, Supra note 15, at 97.

${ }^{13}$ Barnes DW et al, Supra note 31 , at 90.

${ }^{14}$ Law on Determining the Ombudsman's Office Mission, Powers, Organization \& Functioning , Supra note 84, Art. 39

${ }^{15}$ World Bank, Supra note 15, at 185.

${ }^{16}$ Barnes DW et al, Supra note 31, at 92. 
to protect public officials and civil servants from privacy invasions. Under Ethiopian ADR law, the declarations are open to the public and can be accessed by the public at large upon application to the FEACC or to the concerned ethics liaison unit. ${ }^{1}$ The public may access the declarations also through the FEACC's in every two years by way of reports each public officials and civil servants filed declaration.

Unlike Hong Kong and Rwanda's experiences, Ethiopia's ADR law has been treated all disclosed and registered information of an appointee, elected person or a public servant as public information except keeping confidentiality of the family assets. It is worthy to surmise that the Ethiopian ADR law allow the wider public to exercise an oversight role over public officials and civil servants, and help to unearth acts of illicit enrichment. Thought the practice is different, they promote transparency and ensure that an appointee, elected person and a public servant do not hide behind a veil of secrecy while accumulating wealth corruptly.

Despite the ADR law has incorporated positive aspect with regard to accessibility of information, the law fails to answer the questions; what information to be disclosed? When and in what process and procedures to be accessed are not explicitly elaborated. Further, the ADR law fails to make asset declarations available to the public online. As a result, information that is technically public may be unavailable in practice. Therefore, Ethiopia needs to drawn lesson from Hong Kong experience which made asset declarations of high-ranking officials available online to the public, via websites of CSB so as to underpin the objectives of ADR system.

\subsection{Enforcement and Sanctioning}

Sanctions are the final tool by which ADR system can attain its objectives, as well as the final test of its effectiveness. ${ }^{2}$ ADR scheme with unpredictable outcomes undermines the confidence of the public and of the persons obliged to declare in its as there are no meaningful sanctions to back up clear and objective instructions ${ }^{3}$ The lack of sanctions or the imposition of light sanctions may tempt public officials and public servants to breach the ADR laws, with knowledge that there are little accompanying consequences. ${ }^{4}$

There are two broad categories of breach of ADR requirements, namely, breach associated with compliance with the requirement to declare and those breach related to the accuracy of submissions. ${ }^{5}$ The former category includes late filing and non filing. The latter category includes incomplete declarations, and false declarations.

Thus, it is worthy to note that the country's ADR law should be develop sanctions that are targeted, proportionate, and enforced consistently. ${ }^{6}$ Sanctions can be administrative, disciplinary, reputational or criminal, depending on the public officials and public servants position and misdeed. ${ }^{7}$ There is a wide variation of practice in relation to sanction in different context. For instance, in Rwanda, failure to submit declarations; partial declaration or unintentional false declaration amounts to breach of ADR laws that ends up in administrative liability in the form of a fine, as well as blaming; retention of a quarter of the salary; and expulsion. ${ }^{8}$ According to Rwanda's ADR law, the above mentioned administrative measures are given by the Office of the Ombudsman and the amount of the fine shall be deposited in the Public Treasury. However, in Rwanda, there is no express stipulation of criminal liability for breach of ADR system. Despite the Penal Code and ADR law does not specifically mention the criminal accountability for violation of ADR system, certain provisions of the Penal Code can be applied to key filing failures. ${ }^{9}$ Specially, under the crime of perjury, lying on an official document (ADR form) constitutes a criminal offence. ${ }^{10}$

Unlike Rwanda, as discussed above, the ADR system in Hong Kong is designed primarily to detect and prevent conflict of interest for public officials and civil servants rather than to detect illegally obtained assets. But, the POBO provides administrative and criminal sanctions for violations of conflict of interest rules. ${ }^{11}$

In case of Ethiopia, failure to comply with the ADR laws by appointees, elected persons and public servants followed administrative liability in the form of a fine and criminal punishment. Accordingly, Ethiopia's ADR law also recognizes the imposition of penalty on these persons who lately register his assets, fails to disclose his assets for registration, and intentionally submits incorrect disclosure. ${ }^{12}$ However, there is a lack of clarity here regarding

\footnotetext{
${ }^{1}$ ADR Proclamation, Supra note 10, Art. 12.

${ }^{2}$ Ivana M. Rossi et al, Supra note 21, at 105.

${ }^{3}$ Barnes DW et al, Supra note 31, at 71 .

${ }^{4}$ Jorum Duri, 'Assets Declarations by Public Officers in Zimbabwe as Anti-Corruption Tool' (Unpublished LL.M Thesis, University of the Western Cape, Faculty of Law, South African-German Centre for Transnational criminal Justice, 2016), at 41.

${ }^{5}$ Ivana M. Rossi et al , Supra note 31, at 107.

${ }^{6} \mathrm{Id}$, at 105 .

${ }^{7}$ OECD, Supra note 25, at 81.

${ }^{8}$ Law on Determining the Ombudsman's Office Mission, Powers, Organization \& Functioning, Supra note 95, Art. 40, for example, imposes fines of five hundred thousand $(500,000)$ to one million $(1,000,000)$ Rwanda Francs.

${ }^{9}$ World Bank, Supra note 15, at 177.

${ }^{10}$ Ibid.

${ }^{11}$ For instance, Section 12 of that law provides for a fine of approximately US\$13,000, imprisonment for up to one year, and payment of a fine equal to the amount of advantage received by a public official.

${ }^{12}$ ADR Proclamation, Supra note 10, Art.22(1); provides: 'Any appointee, elected person or public servant who fails to disclose his assets for registration in accordance with this Proclamation or intentionally submits incorrect disclosure; shall be punished in accordance with Article
} 
the late registration of assets by an appointee, elected person or a public servant. The law fails to answer the questions: Who has the authority to sanction? Where has the amount of fine obtained from penalty to be deposited? These questions are extremely crucial aspects for an effective ADR system. Otherwise it only becomes political propaganda and will not lead to the desired outcome. On the top of that, the penalty attached to late registration is less deterrent. So, sanction attached to late registration need to be severe enough to have a deterrent impact.

In general, Ethiopia needs to take a good lesson from Rwanda's experience with regard to the authority to sanction. Thus, authority to sanction filling late needs to be clearly identified under Ethiopia's ADR laws. Otherwise its absence can hinder the effectiveness of ADR system objectives to combat corruption. Moreover, Ethiopia needs to derive a lesson from Rwanda in relation to administrative measures such as retention of the salary and expulsion. The fear of retention of the salary and expulsion from public office may enough to force an appointee, elected person and a public servant to submit accurate declarations and discourage to hide illicitly obtained wealthy.

\section{CONCLUSION AND WAY FORWARD}

This article has discussed the ADR law as an anti-corruption tool. A well-designed and structured ADR scheme can be used as a strong tool to combat corruption effectively and eventually lead to successful conviction of it if properly implemented.

The review of disclosure practices shows that there are some basic questions which need to be addressed by ADR laws. These are: (a) what is/are the objectives of ADR law? (b)Who must disclose? (c) What must be disclosed? (d) How often disclosed? (e)Who has access to the information? (f) Is assets and income verified? (g) What is/are the remedies of non-compliances of ADR law? Within these basic questions, the role of Ethiopian ADR law in combating corruption in comparison with the Hong Kong and Rwanda legal framework has been analyzed through the use of primary \& secondary data sources. Accordingly, the study reveals that Ethiopian ADR law does not adequately designed to combat corruption in Ethiopia as compared to the selected jurisdictions. The findings of this research may serve as an input to rectify the weakness and strengthen the current Ethiopian ADR law as well as a stepping stone for conducting such kind of study in the future.

On the basis of the aforementioned conclusion, my recommendation includes:

i. Like that of the experience of Rwanda, Ethiopia should hardly work on the primary focus of illicit enrichment purposes of ADR so as to prosecute corrupt officials.

ii. The ADR law should be revisited in a way to set a mandatory asset declaration as a prerequisite for public officials and civil servants before occupying and before leaving Office.

iii. The FEACC should undertake rigorous and in depth verification of the already registered assets so as to combat corruption like that of Rwanda's experiences.

iv. Akin to the experience of Hong Kong, the FEACC should publish the registered assets of public officials and civil servants, as well as the names of officials who do not comply with ADR law, on their webpage and in a gazette that has high readership.

v. The government should use lifestyle check as a standard of verification approach and an aid to detect, investigate and prosecute corruption. In this regard, the researcher recommends, the government of Ethiopia to borrow experiences from other jurisdictions having ripe verification approach in this regard like the Rwanda, who have better experiences.

vi. The legislature or FEACC should issue law or specific guidelines which would allow public officials and civil servants to determine the monetary value of their assets in monetary figures. If this occurs, declarations will do a better job of showing how wealthy public officials are and of revealing corruption.

vii. There should be application of sanctions for non-submission, late submission and false declaration.

viii. The FEACC and law enforcement bodies should provide adequate training for its employees concerning the purpose of ADR scheme in combating corruption and its remedies for the breach of ADR law.

417 of the Criminal Code(as amended by Corruption Crimes Proclamation no. 881/2015, Art.19).

Further, Art.9 reads: 'If an appointee, elected person or a public servant fails to register his assets within the normal or extended period of registration, he shall pay a fine of Birr 1,000 and register his assets within 30 days." 